\title{
PENGARUH KOMUNIKASI ORGANISASI DAN MOTIVASI KERJA TERHADAP KINERJAKARYAWAN PADA PT.BANK BUKOPIN, TbK. CABANG PALEMBANG
}

\author{
Indah Mawarni \\ Universitas Sjakhyakirti Palembang \\ Syilvia Dewi Septiana \\ PT.. Bank Bukopin, Tbk. Cabang Palembang \\ Email : \\ indahmawarni@unisti.ac.id \\ Syilvia.septiana@bukopin.co.id
}

\begin{abstract}
This study aims to determinethe effect of organizational communication on the performance of employees, the effect of work motivation on the performance of employees and the influence of organizational communication, and work motivation on the performance of employees of PT. Bank Bukopin, Tbk. Palembang Branch both partially and simultaneously.The sample used in this study was a permanent employee of PT. Bank Bukopin, Tbk. Palembang Branch, which has a minimum service period of 2 years and has offices in Palembang Main Branch as many as 30 respondents. The technique used in taking this sample is to use one of the non probability sampling techniques, namely purposive sampling. The analytical method used is descriPT.ive analysis method using path analysis with the SPSS for Windows version 23.The test results of the hypothesis indicate that the variables: (1) organizational communication has a positive effect on employee performance. (2) Work Motivation of Organizational Communication and Work Motivation means that work motivation has a positive and significant effect on employee performance. (3) Organizational Communication and Work Motivation have a positive effect on Employee Performance at PT.Bank Bukopin, Tbk. Palembang Branch. Organizational communication and work motivation together have an effect on employee performance.
\end{abstract}

Keywords: Organizational Communication, Motivation, Employee Performance

\section{PENDAHULUAN}

\section{Latar Belakang Masalah}

PT. Bank Bukopin, Tbk. Cabang Palembang adalah sebuah perusahaan perbankan yang berdiri di Palembang pada tanggal 17 Juli 1996 dan berlokasi di Jalan KaPT.en A. Rivai No 5 Palembang. Pada awal berdiri karyawan PT. Bank Bukopin, Tbk. Palembang hanya terdiri dari beberapa orang saja, mengingat kantor yang ada hanya kantor Cabang Utama, seiring berkembangnya dunia perbankan maka PT. Bank Bukopin, tbk. mulai membuka Kantor Cabang Pembantu 16 Ilir yang beralamat di Jl Masjid Lama No 169 Palembang dan disusul dengan dibukanya Kantor Cabang Pembantu Ilir Barat Permai yang beralamat di Komplek Ilir Barat Permai Blok D1 No 58 kel 24 Ilir Kecamatan Ilir Barat I Palembang. Dengan bertambahnya kantor cabang 
pembantu maka karyawan di PT. Bank Bukopin, Tbk. juga mengalami pertumbuhan yang pesat.

PT.Bank Bukopin, Tbk. dalam menjalankan transaksi hariannya berbasis online diseluruh Indonesia, yang berarti bahwa setiap transaksi perbankan yang dijalankan oleh PT.Bank Bukopin, Tbk. akan langsung dapat dibukukan dan diterima oleh pemilik rekening Bukopin dimanapun mereka berada. Oleh karena itu PT. Bank Bukopin, Tbk. memerlukan suatu system komunikasi yang dapat dengan cepat menyampaikan informasi dan dapat diterima oleh seluruh karyawan dalam waktu yang singkat.

Untuk sistem komunikasi internal, PT. Bank Bukopin, Tbk dalam menyampaikan informasi antar bagian dan antar cabang baik cabang yang berada di dalam satu kota maupun cabang yang ada diluar kota dan antar bagian dicabang yang sama menggunakan system yang disebut BOC (Bukopin Office Communication) dimana system tersebut berupa memorandum atau surat yang disampaikan secara elektronik, selain menghemat kertas system tersebut dapat dikirim dan langsung diterima oleh subordinate atau divisi lain secara langsung sesuai dengan jenjang bagian yang ada di struktur organisasi. BOC tersebut biasanya digunakan oleh PT. Bank Bukopin, Tbk untuk menyampaikan segala informas, baik mengenai kebijakan terbaru, rate bunga pinjaman dan simpanan, informasi umum, informasi terkait adanya perubahan terhadap Panduan Kerja Operasional / SOP, informasi pemberian kredit, permintaan laporan kerja, penyampaian hasil laporan dan sebagainya.

BOC yang digunakan sebagai sarana komunikasi yang digunakan oleh PT. Bank Bukopin, Tbk Cabang Palembang memiliki kelemahan yaitu informasi yang disampaikan tidak luas cakupannya atau dengan kata lain, informasi yang disampaikan terbatas, hanya bisa disampaikan berdasarkan hirarki jabatan yang ada dalam struktur organisasi. Informasi yang disampaikan melalui BOC untuk disebarkan antar divisi hanya bisa dilakukan oleh hirarki yang berada di level Direktur, General Manager, Kepala Divisi saja, untuk tingkat hirarki yang berada dibawahnya hanya bisa meneruskan informasi tersebut kepada sub ordinat yang berada di bawahnya. BOC sebagai sarana komunikasi apabila akan dikirim oleh staf akan terkoneksi kepada supervisi yang membawahinya dan kemudian diteruskan kembali secara berjenjang sesuai hirarki struktur organisasi sampai akhirnya diterima oleh Kepala Divisi dan baru akan diteruskan ke divisi yang akan dituju, sehingga terkadang informasi penting atas suatu kebijakan atau suatu keputusan tidak bisa diterima pada saat yang bersamaan sehingga menjadi kendala dalam pengambilan suatu keputusan dan menghambat kelancaran kerja.

Selain itu pendistribusian BOC yang ada dicabang tidak bisa terkoneksi antar bagian, misalkan dari pimpinan tidak dapat langsung diterima oleh manager operasional dan manager bisnis personal, pimpinan hanya bisa meneruskan informasi yang didapat kepada manager bisnis saja karena manager bisnis berada dalam satu struktur organisasi. Sedangkan untuk Manager Operasional akan mendapatkan informasinya dari Kepala Divisi Operasional dan akan diteruskan ke seluruh karyawan dibawah wewenangnya. Karena BOC hanya dapat diteruskan sesuai jenjang kedudukan yang ada di struktur organisasi. Sehingga apabila ada supervisi yang tidak membuka BOC miliknya, maka karyawan yang ada di bawah supervisinya tidak akan menerima informasi apapun dan akan menghambat kerja.

Sistem komunikasi yang demikian dapat menimbulkan kesalahpahaman karyawan dalam menerima informasi dan dapat juga menimbulkan kemungkinan kesalahan dalam pelaksanaan kerja karena kurangnya informasi dan koordinasi atau pengarahan antara manajeman dan karyawan. Selain itu karyawan juga kurang berinteraksi dengan baik dengan karyawan yang lain didalam perusahaan sehingga mengakibatkan kurangnya informasi yang diterima oleh karyawan yang dapat berdampak buruk bagi hasil kerja karyawan, padahal informasisangat penting diperoleh 
oleh karyawan dalam melaksanakan pekerjaan agar karyawan dapat melakukan perbaikan kinerjanya untuk kedepannya.

Kesalahan dalam melaksanakan kerja dapat berpengaruh atas reward prestasi kerja dan juga terhadap peningkatan karir karyawan. Dimana kinerja yang tidak maksimal akan mempengaruhi besaran bonus, kenaikan gaji, fasilitas yang diberikan oleh peusahaan untuk karyawannya. Di PT. Bank Bukopin, Tbk bonus yang diterima oleh karyawan berdasarkan pada hasil Penilaian Kinerja karyawan yang direview selama 1 tahun, dan dibayarkan di setiap semester. Apabila karyawan memiliki kinerja yang baik akan mendapatkan bonus yang besar sedangkan yang kinerjanya tidak baik tidak akan mendapatkan bonus berupa jasa produksi yang besarannya bonus yang diterima karyawan yang mendapat prestasi yang cemerlang bisa mencapai tujuh kali gaji kotor. Akan tetapi dikarenakan cabang dalam memberikan hasil penilaian juga mendapatkan jatah berupa komposisi nilai atas kinerja karyawan yang menyebabkan tidak semua karyawan yang memiliki kerja baik akan memperoleh hasil yang sangat memuaskan, dan ini dapat menimbulkan hilangnya motivasi karyawan dalam bekerja. Dan hasil penilaian karyawan tersebut juga berpengaruh terhadap jenjang karir karyawan kedepannya, karena untuk bisa mendapatkan promosi naik jabatan harus mendapatkan tiga kali penilaian kinerja tahunan yang baik atau baik sekali.

Dalam rangka mempertahankan bahkan untuk meningkatkan kinerja karyawan yang berarti juga meningkatkan kinerja perusahaan diperlukan komitmen manajemen dalam menerapkan motivasi karyawan agar tetap merasa nyaman dalam bekerja dilingkungan kantor dan lingkungan sesama karyawan. Komitmen ini harus disebarkan kepada seluruh karyawan.Kurangnya informasi kebijakan perusahaan yang disebarkan kepada seluruh karyawan, kondisi lingkungan kerja diperusahaan yang bisa membuat karyawan kurang merasa nyaman, hubungan antara sesame karyawan, pemberian gaji dan reward yang belum sesuai dengan kerja karyawan, membuat motivasi karyawan menjadi lemah.

\section{Rumusan Masalah}

Berdasarkan latar belakang masalah yang telah dikemukakan, maka rumusan masalah dalam penelitian ini adalah:

1. Bagaimana pengaruh komunikasi organisasi terhadap kinerja karyawan PT.. Bank Bukopin Tbk. Cabang Palembang

2. Bagaimana pengaruh motivasi kerja terhadap kinerja karyawan PT.. Bank Bukopin Tbk. Cabang Palembang

3. Bagaimana pengaruh komunikasi organisasi dan motivasi kerja terhadap kinerja karyawan PT.. Bank Bukopin Tbk. Cabang Palembang

\section{Tujuan Penelitian} sebagai berikut:

Berdasarkan pada rumusan penelitian di atas, maka tujuan penelitian ini adalah

1. Menganalisis pengaruh komunikasi organisasi terhadap kinerja karyawan PT. Bank Bukopin Tbk. Cabang Palembang;

2. Menganalisis pengaruh motivasi kerja terhadap kinerja karyawan PT. Bank Bukopin Tbk. Cabang Palembang;

3. Menganalisis pengaruh komunikasi organisasi dan motivasi kerja terhadap kinerja karyawan PT. Bank Bukopin Tbk. Cabang Palembang. 


\section{KAJIAN PUSTAKA}

\section{Komunikasi}

Secara etimologis komunikasi berasal dari bahasa Latin, yaitu cum, kata depan yang artinya dengan atau bersama dengan, dan kata units, kata bilangan yang berarti satu. Dua kata tersebut membentuk kata benda communio, yang dalam bahasa inggris disebut dengan communion, yang berarti kebersamaan, persatuan, persekutuan, gabungan, pergaulan, atau hubungan. Karena untuk melakukan communion, diperlukan usaha dan kerja. Kata communio dibuat kata kerja communicate, yang berarti membagi sesuatu dengan seseorang, tukar menukar, membicarakan sesuatu dengan orang, membicarakan sesuatu dengan orang, memberitahukan sesuatu kepada seseorang, bercakap-cakap, bertukar pikiran, berhubungan, berteman. (Nurjaman dan Umam, 2012).

\section{Komunikasi Organisasi}

Komunikasi organisasi adalah suatu kegiatan organisasional yang menyangkut pertukaran informasi dalam lingkungan organisasi untuk mencapai tujuan yang telah ditetapkan. Menurut Mangkunegara (2011)

Menurut Himstreet dan Baty dalam Purwanto (2011) komunikasi organisasi adalah suatu proses pertukaran informasi antar individu melalui suatu sistem yang biasa (lazim), baik dengan simbol-simbol, sinyal-sinyal, maupun perilaku atau tindakan. Tujuan dari komunikasi adalah menciPT.akan dan saling memberi pengertian (understanding) antara sesama komunikator (pengirim) dan komunikan (penerima), mengandung kebenaran, lengkap, mencakup keseluruhan hal yang menarik dan nyata.

Yang dimaksud dengan komunikasi organisasi adalah upaya yang dilakukan oleh manajemen perusahaan untuk memastikan bahwa seluruh karyawannya mengetahui dan memahami (a). informasi mengenai rencana perusahaan ke depan, (b). kebijakan dan perubahan kebijakan perusahaan dan (c) status kinerja perusahaan dari waktu ke waktu. Upaya tersebut dilakukan melalui berbagai cara; baik interaksi antar pimpinan dengan bawahan, pertemuan rutin maupun sarana-sarana lainnya.

Berdasarkan fungsionalnya arus komunikasi yang terjadi dalam organisasi formal terdiri dari arus vertikal (dari atas ke bawah dan dari bawah ke atas) dan arus horisontal (lateral atau silang) (Stephen P. Robbins, 2008):

a. Arus Komunikasi Vertikal dari Atas ke Bawah

b. Arus Komunikasi Vertikal dari Bawah ke Atas

c. Arus Komunikasi Horisontal

d. Arus Komunikasi Diagonal

\section{Motivasi Kerja}

Motivasi adalah dorongan atau gejolak yang timbul dari dalam diri manusia untuk memenuhi berbagai kebutuhannya sesuai dengan keinginan masing-masing (Afin Murtie, 2012). Dalam bukunya Robbins (2008) mengemukakan motivasi sebagai proses yang menjelaskan intensitas, arah, dan ketekunan seorang individu untuk mencapai tujuannya. Menurut Kadarisma (2012), Motivasi kerja adalah penggerak atau pendorong dalam diri seseorang untuk mau berperilaku dan bekerja dengan giat dan baik sesuai dengan tugas dan kewajiban yang telah diberikan kepadanya.

Motivasi mempersoalkan bagaimana caranya mengarahkan daya dan potensi bawahan, agar mau bekerja sama secara produktif berhasil mencapai dan mewujudkan tujuan yang telah ditentukan (Hasibuan, 2012). Motivasi adalah kondisi yang menggerakan karyawan agar mampu mencapai tujuan dari motifnya (Mangkunegara, 2007). Menurut Saydam (2000) dalam Kadarisma (2012), pengertian motivasi dalam kehidupan sehari-hari diartikan sebagai keseluruhan proses pemberian dorongan atau 
rangsangan kepada para karyawan sehingga mereka bersedia bekerja dengan rela tanpa dipaksa. Berdasarkan pengertian tersebut dapat disimpulkan bahwa motivasi merupakan suatu proses dalam pribadi seseorang yang mendorong keinginan individu untuk melakukan kegiatan-kegiatan yang menjelaskan intensitas, arah, dan ketekunan usaha untuk mencapai suatu tujuan.

\section{Kinerja Karyawan}

Sebuah organisasi memerlukan manusia sebagai sumber daya pendukung utama untuk mencapai tujuan yang telah ditetapkan. Sumber daya manusia yang berkualitas akan turut memajukan organisasi sebagai suatu wadah peningkatan kinerja karyawan. Kedudukan strategis untuk meningkatkan produktivitas organisasi adalah karyawan, yaitu individu-individu yang bekerja pada suatu organisasi atau perusahaan.

Istilah kinerja berasal dari kata Job Performance prestasi kerja atau prestasi sesungguhnya yang dicapai oleh seseorang. Pengertian Kinerja adalah hasil kerja secara kualitas dan kuantitas yang dicapai oleh seorang pegawai dalam melaksanakan tugasnya sesuai dengan tanggung jawab yang diberikan padanya Mangkunegara (2013). Kinerja menurut Fahmi (2014) adalah hasil yang diperoleh oleh suatu organisasi baik organisasi tersebut bersifat profit oriented dan non profit oriented yang dihasilkan selama satu periode waktu. Menurut Simanjuntak (2005) dalam Widodo (2015) Kinerja adalah tingkatan pencapaian hasil atas pelaksanaan tugas tertentu. Simanjuntak juga mengartikan kinerja individu sebagai tingkat pencapaian atau hasil kerja seseorang dari sasaran yang harus dilaksanakan dalam kurun waktu tertentu.

\section{METODE PENELITIAN}

\section{Populasi dan Responden Penelitian}

Peneliti menggunakan salah satu dari teknik non probability sampling yaitu Purposive sampling. Purposive sampling merupakan sampel yang dipilih dengan maksud atau tujuan tertentu. Seseorang dipilih sebagai sampel karena peneliti menilai bahwa seseorang tersebut memiliki informasi yang relevan bagi penelitiannya, dan memenuhi kriteria yang telah di tentukan peneliti sebelumnya (Agusty Ferdinand, 2006). Adapun kriterianya ialah:

1. Karyawan Kantor Cabang Utama PT. Bank Bukopin, Tbk Palembang yang beralamat di Jalan KaPT.en A. Rivai No 5 Palembang

2. Merupakan karyawan yang telah diangkat menjadi karyawan tetap dan memiliki masa kerja minimal 2 tahun.

Berdasarkan kriteria tersebut diatas, maka untuk sample yang digunakan sebagai objek penelitian adalah karyawan dengan jumlah 30 orang. Adapun perincian data sampling sebagai berikut:

Tabel 1.

Sample Karyawan PT. Bank Bukopin, Tbk

Cabang Palembang

\begin{tabular}{|c|l|c|}
\hline No & \multicolumn{1}{|c|}{ UNIT KERJA } & $\begin{array}{c}\text { JUMLAH } \\
\text { KARYAWAN }\end{array}$ \\
\hline 1 & Koordinator & 2 Orang \\
\hline 2 & Staf Layanan Nasabah Junior (Teller, Back Office) & 8 Orang \\
\hline 3 & Staf Layanan Nasabah Senior(Customer Service) & 4 Orang \\
\hline 4 & Staff Layanan Kredit(Administrasi Kredit, Administrasi Laporan) & 4 Orang \\
\hline 5 & Staff Legal & 1 Orang \\
\hline 6 & Staff Investigasi Kredit & 1 Orang \\
\hline 6 & SDM & 1 Orang \\
\hline 7 & Staff Utilities Junior (Sarlog) & 1 Orang \\
\hline 8 & Staff Utilities Senior(Sistem Operasi Komputer) & 1 Orang \\
\hline
\end{tabular}




\begin{tabular}{|l|c|c|}
\hline 9 & Account Officer dan Relation Banking Officer & 7 Orang \\
\hline & JUMLAH & 30 Orang \\
\hline
\end{tabular}

Sumber: PT. Bank Bukopin, Tbk Cabang Palembang

Teknik Pengumpulan Data

Untuk penelitian kali ini peneliti menggunakan teknik kuestioner. Kuestioner (amglet) merupakan teknik pengumpulan data yang dilakukan dengan cara memberikan seperangkat pertanyaan atau pertanyaan tertulis kepada responden untuk dijawabnya, dimana peneliti tidak langsung bertanya jawab dengan responden (Sutopo, 2006). Instrumen atau alat pengumpul datanya juga disebut angket berisi sejumlah pertanyaan pertanyaan yang harus dijawab atau direspon oleh responden (Sutopo, 2006). Responden mempunyai kebebasan untuk memberikan jawaban atau respon sesuai dengan persepsinya.

\section{Teknik Pengumpulan Data}

Sugiyono (2011) mengatakan analisis data merupakan kegiatan setelah data dari seluruh responden terkumpul. Pengolahan data dilakukan dengan cara data yang telah dikumpulkan, diolah, dan disajikan dalam bentuk tabel. Menurut Sugiyono (2011), "Skala Likert digunakan untuk mengukur sikap, pendapat dan persepsi seseorang atau sekolompok orang tentang fenomena sosial." Skala likert yang diukur, kemudian dijabarkan menjadi indikator variabel dan dijadikan sebagai titik tolak untuk menyusun item instrumen yang berupa pernyataan. Jawaban setiap item instrumen yang menggunakan Skala Likert mempunyai skor mulai dari angka 5-4-3-2-1.

\section{Teknik Analisis Data}

\section{Uji Instrumen Penelitian}

Instrumen penelitian adalah alat yang digunakan oleh peneliti untuk mengukur variabel yang diteliti. Pengumpulan data berupa penggunaan kuesioner sebagai instrument penelitian harus memenuhi dua kriteria, yaitu valid dan reliable. Untuk itu sebelum kuisioner disebar harus dilakukan uji validitas dan uji reliabilitas. Hasil penelitian yang berupa jawaban atas pemecahan masalah tergantung pada kualitas data yang dianalisis dan instrument yang digunakan untuk mengumpulkan data tersebut.

\section{a. Uji Validitas}

Validitas yang dimaksud adalah keadaan yang menggambarkan tingkat instrumen yang bersangkutan mampu mengukur apa yang akan diukur (Arikunto, 2013). Alat ukur yang tidak valid adalah yang memberikan hasil ukuran yang menyimpang dari tujuannya, penyimpangan pengukuran ini disebut dengan kesalahan (error) atau varian.

\section{b. Uji Reliabilitas}

Metode tersebut penulis gunakan karena skor alat ukur yang dipakai dalam penelitian ini berbentuk skala, dan metode Cornbach's Alpha merupakan metode yang paling sesuai untuk menghitung nilai reliabilitas pada skor skala ataupun rentangan (Priyatno, 2013). Uji reliabilitas adalah istilah yang dipakai untuk menunjukkan sejauh mana suatu hasil pengukuran relatif konsisten apabila pengukuran diulangi lagi lebih dari sekali. Nilai koefisien reliabilitas yang baik adalah diatas 0,7 (cukup baik), di atas 0,8 (baik).

\section{Uji Asumsi Klasik}

\section{a. Uji Normalitas}

Menurut Ghozali (2013:110) uji normalitas bertujuan untuk mengetahui apakah masing-masing variabel berdistribusi normal atau tidak. Uji normalitas diperlukan 
karena untuk melakukan pengujian-pengujian variabel lainnya dengan mengasumsikan bahwa nilai residual mengikuti distribusi normal. Jika asumsi ini dilanggar maka uji statistik menjadi tidak valid dan statistic parametrik tidak dapat digunakan.

\section{b. Uji Multikolinieritas}

Uji multikolinearitas bertujuan untuk menguji apakah model regresi ditemukan adanya korelasi antar variabel bebas (independen). Karena model regresi yang baik seharusnya tidak terjadi korelasi di antara variabel independen. Uji multikolinearitas dilakukan dengan melihat nilai toleransi dan Variance Inflation Factor (VIF) dari hasil analisis dengan menggunakan aplikasi SPSS.

\section{c. Uji Heteroskedastisitas}

Menurut Ghozali (2013) Uji ini bertujuan untuk menguji apakah dalam model regresi terjadi ketidaksamaan variance dari residual satu pengamatan ke pengamatan yang lain. Jika variance dari residual tetap maka disebut homokedastisitas dan jika berbeda disebut heterokedastisitas. Ada tidaknya heterokedastisitas dapat dilihat pada grafik scatterplot, yaitu titik yang menyebar secara acak, baik di atas maupun di bawah angka 0 pada sumbu Y.

\section{Model Analisis Data/ Analisa Regresi Berganda}

Analisis ini digunakan untuk mengetahui apakah ada pengaruh antara variabel $\mathrm{X}_{1}$ (Komunikasi Organisasi) dan $\mathrm{X}_{2}$ (Motivasi Kerja) terhadap variabel $\mathrm{Y}$ (Kinerja karyawan).

Rumus yang digunakan:

$$
Y=\alpha+\beta_{1} X_{1}+\beta_{2} X_{2}+e
$$

Dimana:

$Y=$ Kinerja Karyawan

$\alpha=$ Konstanta

$\beta_{1}, \beta_{2}=$ Koefisien regresi variable independen

$X_{1}=$ Komunikasi Organisasi

$X_{2}=$ Motivasi Kerja

$\mathrm{e}=$ Standar error $/$ variabel pengganggu

\section{Pengujian Hipotesis}

Dalam penelitian ini, pengujian hipotesis yang digunakan antara lain adalah pengujian signifikansi individual atau parsial (Uji t) dan pengujian signifikansi bersamasama atau simultan (Uji F).

\section{Analisa Determinasi $\left(\mathbf{R}^{2}\right)$}

Untuk menguji seberapa jauh kemampuan model penelitian dalam menerangkan variabel dependen (goodness of fit), yaitu dengan menghitung koefisien determinasi $\left(\mathrm{R}^{2}\right)$.

\section{HASIL DAN PEMBAHASAN}

\section{Hasil Penelitian}

Berdasarkan hasil uji validitas menunjukkan bahwa seluruh hasil nilai $\mathrm{R}$ adalah signifikan (terdapat tanda bintang pada angka pearson correlation) dengan nilai signifikansi lebih kecil dari nilai alpha (Nilai pada Sig. (2-tailed) < 0,05). Dengan demikian instrumen kuesioner telah valid dan dapat digunakan dalam penelitian.

Berdasarkan hasil uji reliabilitas untuk variabel Y, didapati hasil bahwa butirbutir pertanyaan/pernyataan pada kuesioner untuk variabel $\mathrm{Y}$ berupa kinerja karyawan telah reliabel dan dapat digunakan dalam penelitian. Hal ini terlihat dari nilai Cronbach's Alpha yang lebih besar dari 0,6 $(0,716>0,6)$. 
Teori nilai $\mathrm{R}^{2}$ menggambarkan seberapa besar variable bebas mempengaruhi besarnya variable terikat. Nilai $\mathrm{R}^{2}$ sebaiknya lebih besar dari 0,6 (60 persen). Berdasarkan hasil pengolahan data dengan menggunakan alat bantu SPSS versi 23 diperoleh hasil sebagai berikut:

Tabel 2.

Tabel Koefisien Determinasi $\left(\mathbf{R}^{2}\right)$ Model Summary ${ }^{b}$

\begin{tabular}{|l|c|r|r|r|}
\hline Model & R & R Square & Adjusted R Square & Std. Error of the Estimate \\
\hline 1 & $.705^{\mathrm{a}}$ & .697 & .660 & .602 \\
\hline
\end{tabular}

a. Predictors: (Constant), Motivasi Kerja, Komunikasi Organisasi

b. Dependent Variable: Kinerja Karyawan

Sumber: Hasil Perhitungan SPSS versi 23

Berdasarkan hasil regresi maka model regresi yang diperoleh adalah sebagai berikut:

$$
Y=6,721+0,125 X_{1}+0,079 X_{2}+e
$$

Nilai t hitung untuk $\mathrm{X}_{1}$ adalah sebesar 2,899 dengan nilai signifikansi (sig) adalah sebesar 0,001. Nilai signifikansi (sig) tersebut lebih kecil dari nilai alpha $(0,001<0,05)$. Hal ini berarti varibel $X_{1}$ berpengaruh signifikan terhadap variable Y.Uji t dapat juga dilakukan dengan membandingkan nilai t-hitung $>\mathrm{t}$-tabel. Nilai t-tabel dapat dilihat pada table distribusi $\mathrm{t}$ dengan ketentuan $\alpha=0.05, \mathrm{~N}=30, \mathrm{k}=3$ sehingga nilai degree of freedom adalah $27(\mathrm{Df}=\mathrm{N}-\mathrm{k}=27)$. Nilai t table yang didapat adalah 2,052. Nilai $\mathrm{t}$ hitung > t-tabel $(2,899>2,052)$. Dengan demikian maka variable $\mathrm{X}_{1}$ berpengaruh signifikan terhadap variable $\mathrm{Y}$.

Nilai t hitung untuk $\mathrm{X}_{2}$ adalah sebesar 2.099 dengan nilai signifikansi (sig) adalah sebesar 0.001. Nilai signifikansi tersebut lebih kecil dari nilai alpha $(0,001<0,05)$. Hal ini berarti varibel $\mathrm{X}_{2}$ berpengaruh signifikan terhadap variable Y.Uji $t$ dapat juga dilakukan dengan membandingkan nilai t-hitung $>\mathrm{t}$-tabel. Nilai t-tabel dapat dilihat pada tabel distribusi t dengan ketentuan $\alpha=0,05, \mathrm{~N}=30, \mathrm{k}=3$ sehingga nilai degree of freedom adalah $27(\mathrm{Df}=\mathrm{N}-\mathrm{k}=27)$. Nilai t table yang didapat adalah 2,052. Nilai thitung > t-tabel $(2,099>2,052)$. Dengan demikian maka variable $\mathrm{X}_{2}$ berpengaruh signifikan terhadap variable Y.

Berdasarkan output regresi diatas didapat nilai F-hitung adalah sebesar 13,351 dengan nilai signifikansi (sig.) sebesar 0.000. Nilai signifikansi lebih kecil dari nilai alpha $(0.000<0.05)$. Dengan demikian variable variable bebas secara simultan berpengaruh signifikan terhadap variable $\mathrm{Y}$.

Berdasarkan table $\mathrm{F}$ dengan ketentuan $\mathrm{df}_{1}=\mathrm{k}-1=3-1=2$, dan $\mathrm{df}_{2}=\mathrm{n}-\mathrm{k}=30-3=27$ dan alpha $=0,05$ didapat nilai $F$ table adalah sebesar 3.35. Nilai $F$ hitung $>F$ table $(13.351>3.35)$. Dengan demikian variable-variabel bebas secara simultan berpengaruh signifikan terhadap variable $\mathrm{Y}$.

\section{Pembahasan}

Berdasarkan hasil pengujian secara statistik dapat terlihat secara simultan bahwa komunikasi organisasi dan motivasi kerja berpengaruh terhadap kinerja karyawan pada PT. Bank Bukopin, Tbk. Cabang Palembang. Penjelasan mengenai masing-masing variable sebagai berikut:

1. Pengaruh Komunikasi Organisasi terhadap Kinerja Karyawan pada PT. Bank Bukopin, Tbk. Cabang Palembang

Berdasarkan hasil uji parsial, komunikasi organisasi menunjukkan nilai t-hitung lebih besar dari t-tabel $(2,899>2,052)$ atau sig $(0,001<0,05)$, berarti komunikasi 
organisasi berpengaruh positif dan signifikan terhadap Kinerja Karyawan. Berdasarkan dari uji koefisien determinasi juga diketahui bahwa komunikasi organisasi berpengaruh terhadap kinerja karyawan. Dari hasil analisa uji koefisien determinasi bisa terlihat bawa nilai $\mathrm{R}^{2}$ adalah 69,7 berarti bahwa komunikasi organisasi berpengaruh terhadap kinerja karyawan sebesar $67,7 \%$, Sementara sisanya 30,3\% dipengaruhi oleh variable lain. Dari hasil analisa yang telah dilakukan diatas menunjukkan bahwa komunikasi organisasi di PT. Bank Bukopin, Tbk. Cabang Palembang untuk komunikasi vertical pimpinan sudah memberikan instruksi yang dapat dimengerti oleh karyawan, pimpinan juga menjelaskan prosedur untuk setiap pekerjaan, pimpinan memberikan teguran bila karyawan melakukan kesalahan dan memberikan pujian bila menjalankan tugas dengan baik, pimpinan menerima saran yang diberikan karyawan, dan memberikan respon yang baik atas laporan yang diberikan.

Untuk komunikasi horizontal antar karyawan sudah saling memberikan informasi terbaru tentang pekerjaan, pendistribusian tugas sudah dijalankan dan pimpinan dan karyawn telah melakukan rapat untuk mendiskusikan konflik, sedangkan untuk komunikasi diagonal komunikasi antar karyawan dengan beda divisi terlah terjalin dengan baik, sehingga mempermudah memperoleh informasi dari bagian lain. Hal ini didukung oleh teori yang menyatakan bahwa komunikasi organisasi adalah suatu kegiatan operasional yang menyangkut pertukaran informasi dalam lingkungan organisasi untuk mencapai tujuan yang telah ditetapkan, Mangkunegara (2011). Mendorong proses perbaikan organisasi, memfasilitasi perubahan, dan mendorong tercapainya tujuan organisasi melalui perubahan perilaku karyawan (Wyatt, 2006 dalam Dasgupta et al., 2013).

2. Pengaruh Motivasi Kerja terhadap Kinerja Karyawan pada PT.Bank Bukopin, Tbk. Cabang Palembang

Berdasarkan hasil uji t, motivasi kerja menunjukkan t-hitung lebih besar dari ttabel $(2,099>2,052)$, berarti motivasi kerja berpengaruh positif dan signifikan terhadap kinerja karyawan. Berdasrkan dari uji koefisien determinasi juga diketahui bahwa motivasi kerja berpengaruh terhadap kinerja karyawan. Dari hasil analisa uji koefisien determinasi bisa terlihat bawa nilai $\mathrm{R}^{2}$ adalah 69,7 berarti bahwa motivasi kerja berpengaruh terhadap kinerja karyawan sebesar 69,7\%, Sementara sisanya 30,3\% dipengaruhi oleh variable lain

Dari hasil analisa yang telah dilakukan diatas hal ini menunjukkan karyawan PT. Bank Bukopin, Tbk. Cabang Palembang memiliki motivasi kerja dimana kondisi kerja di perusahaan mampu memberikan rasa nyaman bagi karyawan, gaji yang diberikan oleh perusahaan sesuai dengan pekerjaan yang dilakukan, perusahaan memberikan informasi jika terjadi perubahan kebijakan dalam perusahaan, hubungan antar karyawan mampu meningkatkan professional kerja, setiap karyawan memiliki kesempatan yang sama untuk mendapatkan promosi jabatan, fasilitas yang disedian oeh perusahaan sesuai dengan kebutuha karyawan, jaminan kerja yang diberikan perusahaan dapat memotivasi karyawan, perusahaan memberikan reward atas prestasi kerja karyawan, karyawan termotivasi untuk meningkatkan jabatan, dan karyawan tertantang untuk mendapatkan peningkatan jabatan. Hal ini berarti bahwamotivasi yang tinggi dari karyawan dapat meningkatkan kinerja karyawan. Hal ini sesuai dengan pendapat Munandar (2001), yang menyatakan bahwa ada hubungan positif antara motivasi dan kinerja dengan pencapaian prestasi, artinya manajer yang mempunyai motivasi prestasi yang tinggi cenderung mempunyai kinerja tinggi, sebaliknya mereka yang mempunyai kinerja rendah dimungkinkan karena motivasinya rendah. Hal ini sejalan dengan penelitian Desy Ernika (2016) Pengaruh Komunikasi Organisasi dan Motivasi Terhadap Kinerja Karyawan Pada PT. Bank Bukopin, Tbk. Cabang Palembang.

3. Pengaruh Komunikasi Organisasi dan Motivasi Kerja terhadap Kinerja Karyawan pada PT. Bank Bukopin, Tbk. Cabang Palembang 
Berdasarkan hasil uji F menunjukkan nilai F-hitung sebesar 13,351 nilai ini lebih besar dari F-tabel yaitu 3,35 atau F-hitung 13,351 > Ftabel 3.35 dengan probabilitas 0.000. Karena nilai probabilitas jauh lebih kecil dari 0.05 maka komunikasi organisasi dan motivasi kerja secara bersama sama berpengaruh terhadap kinerja karyawan. Berdasarkan dari uji koefisien determinasi menunjukkan hasil bahwa komunikasi organisasi dan motivasi kerja berpengaruh terhadap kinerja karyawan. Dari hasil analisa uji koefisien determinasi bisa terlihat bawa nilai $\mathrm{R}^{2}$ adalah 69,7 berarti bahwa komunikasi organisasi dan motivasi kerja berpengaruh terhadap kinerja karyawan sebesar $69,7 \%$, Sementara sisanya 30,3\% dipengaruhi oleh variable lain. Dari hasil analisa yang telah dilakukan diatasHal ini dirasakan pada karyawan PT. Bank Bukopin, Tbk. Cabang Palembang bahwa komunikasi organisasi dan motivasi kerja berpengaruh terhadap kinerja karyawan.

Hal ini menunjukkan bahwa karyawan PT.Bank Bukopin, Tbk. Cabang Palembang memiliki tujuan dan kemampuan dalam organisasi, dan karyawan mengerti akan adanya target yang harus dicapai, volume pekerjaan yang diberikan perusahaan sesuai dengan kemampuan, kesadaran untuk menyelesaikan pekerjaan dengan rapidan selalu teliti dalam melaksanakan pekerjaan yang mereka terima. Hal ini sejalan dengan penelitian Rest Fawzia Anjani 2014 Pengaruh Motivasi, Komunikasi dan Lingkungan Kerja Terhadap Kinerja Karyawan Fakultas Ekonomi dan Bisnis UMS

\section{SIMPULAN DAN SARAN}

\section{Simpulan}

Berdasarkan hasil dan pembahasan yang telah dilakukan oleh peneliti pada bab sebelumnya tentang pengaruh variabel independen (Komunikasi Organisasi dan Motivasi Kerja) terhadap variabel independen (Kinerja Karyawan), maka peneliti dapat menarik beberapa kesimpulan sebagai berikut:

1. Dari analisis uji simultan yang dilakukan, maka dapat disimpulkan bahwa komunikasi organisasi dan motivasi kerja secara bersama-sama (simultan) berpengaruh terhadap kinerja karyawan. Hal ini dibuktikan dengan hasil analisis uji simultan yang menunjukkan bahwa nilai signifikansi dari hasil olah data lebih kecil dari tingkat signifikansi yang ditentukan yaitu $0,000<0,05$. Berdasarkan output regresi dengan menggunakan program SPSS versi 23 didapat nilai $F$ hitung adalah sebesar 13,351 dan berdasarkan table $\mathrm{F}$ dengan ketentuan $\mathrm{df}_{1}=\mathrm{k}-1=3-1=2$, dan $\mathrm{df}_{2}$ $=\mathrm{n}-\mathrm{k}=30-3=27$ dan alpha $=0,05$ didapat nilai F-tabel adalah sebesar 3,35. Nilai Fhitung > F-tabel $(13,351>3,35)$. Dengan komunikasi organisasi dan motivasi kerja secara simultan berpengaruh signifikan terhadap kinerja karyawan.

2. Dari hasil analisis uji parsial yang dilakukan dapat ditarik kesimpulan bahwa nilai signifikansi dari komunikasi organisasi menunjukkan angka sebesar 0,001 $<0,05$, hal ini berarti komunikasi organisasi berpengaruh signifikan terhadap kinerja karyawan.

3. Dari hasil analisis uji parsial yang dilakukan dapat ditarik kesimpulan bahwa nilai signifikansi dari motivasi kerja menunjukkan angka sebesar $0,001<0,05$, maka hal ini berarti motivasi kerja berpengaruh signifikan terhadap kinerja karyawan.

4. Berdasarkan dari uji koefisien determinasi juga diketahui bahwa komunikasi organisasi dan motivasi kerja berpengaruh terhadap kinerja karyawan. Dari hasil analisa uji koefisien determinasi bisa terlihat bawa nilai $\mathrm{R}^{2}$ adalah 69,7 berarti bahwa komunikasi organisasi berpengaruh terhadap kinerja karyawan sebesar 69,7\%, Sementara sisanya $30,3 \%$ dipengaruhi oleh variable lain

5. Dari hasil analisis diperoleh angka (Adjusted $R$ Square) sebesar $0.660(66 \%)$. Halini menunjukkan bahwa presentase sumbangan pengaruh variabel independen (komunikasi organisasi, dan motivasi kerja) terhadap variabel dependen (kinerja karyawan) sebesar 66\% atau dengan kata lain variabel independen (komunikasi 
organisasi dan motivasi kerja) yang digunakan dalam model mampu menjelaskan sebesar 66\% variabel dependen (kinerja karyawan), sedangkan sisanya sebesar 34\% dipengaruhi atau dijelaskan oleh variabel lain yang tidak dimasukkan dalam penelitian ini.

\section{Saran}

Dengan melihat hasil yang didapatkan maka PT. Bank Bukopin, Tbk. Cabang Palembang hendaknya mempertimbangkan komunikasi organisasi yang sekarang diterapkan untuk meningkatkan kinerja karyawannya bila ingin meningkatkan arus informasi dapat tesampaikan dengan baik kepada seluruh karyawan. Oleh karena itu, saran bagi PT. Bank Bukopin, Tbk. Cabang Palembang yang ingin disampaikan yaitu untuk memperbaharui sistem komunikasi berupa komunikasi elektronik yang selama ini digunakan sehingga penyebaran informasi tidak terputus hanya pada bagian tertentu, dan dapat diterima oleh seluruh karyawan yang memerlukan informasi sehingga dengan tersampaikan segala informasi penting dengan tepat waktu dapat mempercepat kerja sehingga dapat menghasilkan hasil yang maksimal dan cepat tanpa mengabaikan ketentuan yang ada. Dengan bekerja secara cepat, tepat dan zero kesalahan maka diharapkan hasil kerja yang maksimal dan secara langsung berpengaruh terhadap pencapaian kerja karyawan untuk dapat menerima reward atas hasil kerja yang telah dilakukan.

\section{DAFTAR PUSTAKA}

Ade, K. 2014.Pengaruh Kapasitas Sumber Daya Manusia, Pemanfaatan Teknologi Informasi, dan Sistem Pengendalian Intern Akuntansi Terhadap Nilai Informasi Pelaporan Keuangan Pemerintah Daerah Pemerintah Kota Bandar Lampung. Bandar Lampung: Fakultas Ekonomi Bisnis. UNILA.

Anjani, Resty Fawzia. 2014.Pengaruh Motivasi, Komunikasi dan Lingkungan Kerja Terhadap Kinerja Karyawan Fakultas Ekonomi dan Bisnis UM.Fakultas Ekonomi dan Bisnis Universitas Muhammadiyah Surakarta.

Ernika, Desy. 2016.Pengaruh Komunikasi Organisasi dan Motivasi Terhadap Kinerja Karyawan Pada PT Inti Tractors Samarinda, Fakultas Ilmu Sosial dan Ilmu Politik, Universitas Mulawarman.

Eunson, Baden. CommUnicating in the 21 st century.

I, Fahmi. 2014. Analisis Laporan Keuangan. Bandung: Alfabeta.

Handoko, T. Hani. 2015.Manajemen Edisi 2. Yogyakarta: BPFE.

Hasibuan, Malayu. 2012.Manajemen Sumber Daya manusia. Jakarta: PT. Bumi Aksara. . 2013. "Manajemen Sumber Daya Manusia". Cetakan Ketujuh Belas. Jakarta: PT. Bumi Aksara.

Himstreet, William C; Wayne Murlin Baty. 2011.Business Communicationss: Principles and Methods. Boston: PWSKent Publishing Company.

Kadarisman, M. Manajemen Pengembangan Sumber Daya Manusia. Edisi Pertama, Cetakan pertama.Jakarta: Rajawali Press.

Mangkunegara, A.A. Anwar Prabu. 2007. "Sumberdaya Manusia Perusahaan". Bandung: PT Remaja Rosdakarya. 
2009. "Manajemen Sumber Daya Perusahaan”. Cetakan Kesepuluh. Bandung: PT Remaja Rosdakarya.

Aditama.

2013.Manajemen Sumber Daya Manusia. Bandung :Perusahaan Remaja Rosdakarya

Muhammad, Fadel. 2009.Reinventing Government (Pengalaman Dari Daerah). Jakarta: PT. Elex Media Komputindo.

Mulyana, Deddy. 2013. Ilmu Komunikasi: Suatu Pengantar. Bandung. . 2014.Ilmu Komunikasi: Suatu Pengantar. Cetakan ke 18. Bandung: PT. Remaja Rosdakarya.

Murtie,Afin. 2012. Menciptakan SDM Berkualitas. Jakarta: PT. Gelora Aksara Pratama.

Nurjaman, Kadar \& Khaerul Umam. 2012. Komunikasi \& Public Relation. Bandung: PustakaSetia.

Pasolong, Harbani. 2012. Metode Penelitian Administrasi Publik. Bandung: Alfabeta.

--------. 2010. Teori Administrasi Publik. Bandung: Alfabeta.

Siagian, Sondang P. 2012. Teori Motivasi dan Aplikasinya. Jakarta: Rineka Cipta.

Purwanto, Djoko. 2011. Komunikasi Bisnis. Jakarta: Penerbit Erlangga.

Anjani, Resty Fawzia. 2014.Pengaruh Motivasi, Komunikasi dan Lingkungan Kerja Terhadap Kinerja Karyawan Fakultas Ekonomi dan Bisnis UM.Fakultas Ekonomi dan Bisnis Universitas Muhammadiyah Surakarta.

Sapre dalam Usman. 2013.Manajemen. Jakarta: Erlangga.

Sedarmayanti. 2001.Sumber Daya Manusia dan Produktivitas Kerja. Bandung: Mandar Maju.

------2009. Sumber Daya Manusia dan Produktivitas Kerja.Bandung: MandarMaju.

SP, Robbins, Judge.2008. Perilaku Organisasi Buku 2.Jakarta: Salemba.

Sri Sundari Candra. 2016.Pengaruh Komunikasi dan Motivasi Kerja terhadap Kinerja Karyawan PT. NET21PLUS. Akademi Akuntasi Permata Harapan.

Sugiyono. 2012.Metode Penelitian Kuantitatif, Kualitatif dan R\&D. Bandung: Alfabeta. 2013. Statistika Untuk Penelitian. Bandung: Alfabeta.

Suhardi. 2013.The Science of Motivation (Kitab Motivasi).Jakarta: PT. Gramedia.

Wibowo. 2016.Manajemen Kinerja - Edisi Kelima -Kategori: Manajemen, Cetakan Ke10.

Widodo, Suparno Eko. 2015.Manajemen Pengembangan Sumber Daya Manusia.Yoyakarta: Pustaka Pelajar.

Wilson, Bangun. 2012.Manajemen Sumber Daya Manusia. Bandung: Erlangga. 